Proc. Estonian Acad. Sci. Geol., 2001, 50, 3, 139-148

\title{
SEARCH FOR THE DOSE-SENSITIVE OPTICALLY STIMULATED LUMINESCENCE RESPONSE IN NATURAL CARBONATES
}

\author{
Ivar JAEK ${ }^{\mathrm{a}}$, Galina HÜTT $^{\mathrm{a}}$, Ilmar RAMMO ${ }^{\mathrm{b}}$, and Valeri VASILCHENKO ${ }^{\mathrm{b}}$ \\ ${ }^{a}$ Institute of Geology, Tallinn Technical University, Estonia pst. 7, 10143 Tallinn, Estonia; \\ galinap@physic.ut.ee \\ b Institute of Experimental Physics and Technology, University of Tartu, Tähe 4, 51010 Tartu, \\ Estonia
}

Received 20 November 2000, in revised form 23 March 2001

\begin{abstract}
Carbonates of different origin, such as Iceland spar, calcites, and mollusc shells, used as electron spin resonance and thermoluminescence palaeodosimeters, were studied in order to determine their suitability for optically stimulated luminescence dating. The stimulation/excitation spectra of the afterglow of the samples were recorded in the wavelength range of 250-1100 nm. The results of the study show that these spectra present either excitation spectra of $\mathrm{Mn}^{2+}$ ion fluorescence (samples of calcites and Iceland spar, red emission recorded) or the excitation spectra of primary phosphorescence (samples of carbonates, including mollusc shells; short-wave emission bands recorded). The recorded stimulation spectra revealed no spectral bands sensitive to stimulation by ionizing radiation, which would disappear as a result of heating and could thus be related to deep traps in carbonates, needed in dating. The causes of this situation which is unusual in luminescent crystals, including luminescence (palaeo)dosimeters, and the ways of overcoming the difficulties in optical dating of natural carbonates are discussed.
\end{abstract}

Key words: carbonates, optical dating, optically stimulated afterglow.

\section{INTRODUCTION}

A large number of natural materials contain calcium carbonates, which explains the wide interest in using the latter to date archaeological events, biotic and geological processes, such as the last heating of firestone as a result of human activities, the growth periods of corals (Gallois et al. 1979) and mollusc shells (Ninagawa et al. 1992), the crystallization events of calcite in carbonate deposits (Turetken et al. 1979; Aitken \& Bussel 1982; Li 1988). 
The first attempts to date carbonates by luminescence methods were made by Lewis (1968), Wintle (1975), and Nambi \& Mitra (1978). Wintle (1978) determined several factors complicating the thermoluminescence (TL) measurement process of this material, e.g. chemi-triboluminescence and shift of the emission band during heating. Roque et al. (2001) describe a recent attempt to date calcites and the ways of evading a spurious TL signal from calcite by heating it in $\mathrm{CO}_{2}$ instead of $\mathrm{N}_{2}$ atmosphere. However, the difficulties, connected with TL dating of carbonates, are still unresolved.

The electron spin resonance (ESR) method is widely used for mollusc shell dating. Nevertheless, there arise difficulties with interpreting the complex ESR spectra of shells and separating the decisive signals from integrated ESR spectra.

Hence, the optically stimulated luminescence (OSL) dating method was tested to overcome the above-mentioned problems (Huntley et al. 1985). It proved very effective for quartz and feldspar, and thus a detailed dating procedure was worked out for these materials (e.g. Aitken 1998). Evidently, it is necessary to find out if similar methods can be used for dating objects containing natural carbonates. The first step in this direction is to measure the basic characteristics of OSL of natural carbonates, first of all the stimulation spectra and the optical and thermal stability of the stimulation bands. At the LED99 Conference in Rome a group of researchers (Okura et al. 1999) reported that they observed an effective OSL stimulation in the spectral region of $380-430 \mathrm{~nm}$, detecting emission at wavelengths of 580-670 nm, which belong to $\mathrm{Mn}^{2+}$ ion fluorescence (Marfunin 1979). Unfortunately these results have not been developed further or even confirmed by other scientists.

We investigated the OSL of carbonates of different origin using the so-called optically stimulated afterglow (OSA) method (Jaek et al. 1999). Basing on the study results, we discuss below the possibility of applying the OSL method to dating natural carbonates.

\section{MATERIALS AND METHODS}

The OSL measurement apparatus described in Hütt et al. (2001) was used to measure secondary phosphorescence intensity after a pre-determined time interval after the termination of the stimulating impulse. It was improved to allow change of the time delay $\Delta t$ between the stimulation termination and the beginning of recording the afterglow between 1.5 and $150 \mathrm{~ms}$ rather than using a constant $\Delta t=50 \mathrm{~ms}$ as in the old version. This new device yields higher initial phosphorescence intensity (with $\Delta t=1.5 \mathrm{~ms}$ ) and also data concerning the characteristic time of phosphorescence decay (by comparing the intensities measured using the delay times of 1.5 and $150 \mathrm{~ms}$ ).

A $1000 \mathrm{~W}$ Xe-lamp was used as a stimulating radiation source. The spectral separation of the stimulated radiation was realized by a SPM-2 monochromator 
with a quartz prism. For recording a photomultiplier FEU-39 with a quartz window or FEU-79 was used. The photoluminescence radiation spectra were measured using a monochromator MDR-6 with a photomultiplier FEU-83.

Samples of the following materials were selected for our study:

1. monocrystalline Iceland spar of Yakutia (Russia);

2. calcite from Silurian dolomite deposits of Saaremaa Island (West Estonia);

3. calcite from Ordovician dolomite deposits of Vasalemma (West Estonia);

4. recent mollusc shells (Mya arenaria) from the shore of the Gulf of Finland (Pirita Bay, North Estonia);

5. recent mollusc shells (Mya arenaria) from the shore of the Baltic Sea (West Lithuania);

6. ancient (Eemian Interstadial) mollusc shells (Cerastoderma sp.) from the shore of the Baltic Sea (Suurupi, North Estonia).

\section{RESULTS}

\section{Iceland spar}

The photoluminescence spectra of Iceland spar (Fig. 1) were detected at room temperature and at the temperature of liquid nitrogen. We observed a wide, clearly not elementary band. At longer wavelengths it contains emission of $\mathrm{Mn}^{2+}$ ions and of iron (the band near $760 \mathrm{~nm}$ ). The blue region is dominating.

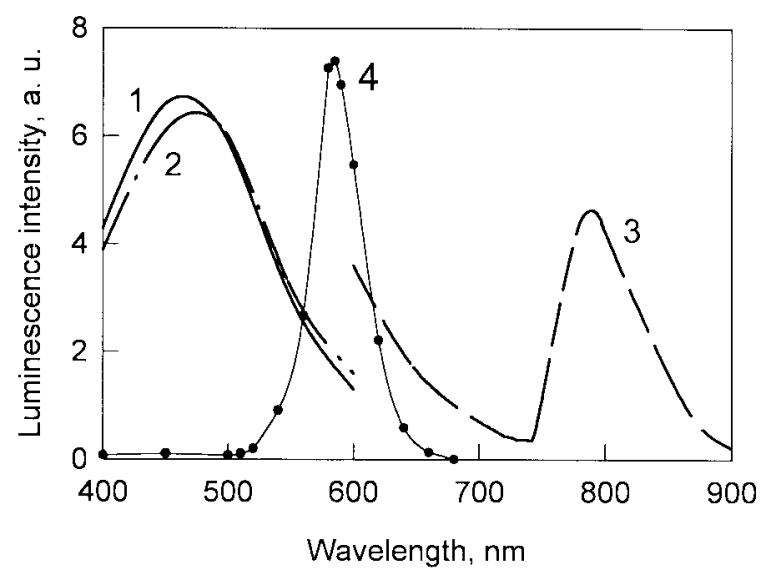

Fig. 1. Photoluminescence (1-3) and X-ray luminescence (4) spectra of Iceland spar: 1, excitation by a $300 \mathrm{~W}$ Hg-lamp (313-365 nm) at room temperature; 2, the same at $90 \mathrm{~K}$; 3, excitation by a $436 \mathrm{~nm}$ spectral line at room temperature; 4, X-ray excitation at room temperature (identical red emission dominates also in the phosphorescence and optically stimulated luminescence). 
In X-ray luminescence spectra (Fig. 1, curve 4) the red emission band $(\lambda=585 \mathrm{~nm})$, caused by $\mathrm{Mn}^{2+}$ ions, is dominating. It should be pointed out that the X-ray luminescence characterizes the emission in recombination processes, e.g. phosphorescence, thermally stimulated luminescence and OSL, that is, exactly the emission used in the luminescence dating process.

The OSA stimulation spectra of the same sample (Fig. 2) were detected for two delay times $\Delta t$ and had practically identical shapes. They only differed in their initial photoluminescence intensity value by about 40 times, which corresponds to a decay time of about $40 \mathrm{~ms}$ in good accordance with published data (e.g. Bahtin \& Gorobets 1992).

The OSA stimulation spectra (Fig. 2), acquired using the blue emission $(\tau \approx 0.02 \mu \mathrm{s})$ and separated by an optical light filter $\left(\lambda_{m}=410 \mathrm{~nm}\right)$, yielded a characteristic phosphorescence decay of about $0.2 \mathrm{~s}$. Hence, the phosphorescence is related to a release of charge carriers from shallow trap levels. But even in this case the OSA signal intensity remains unchanged in the process of X-raying as well as in heating. The complicated phenomena recorded in the process of optical bleaching are thoroughly discussed below.

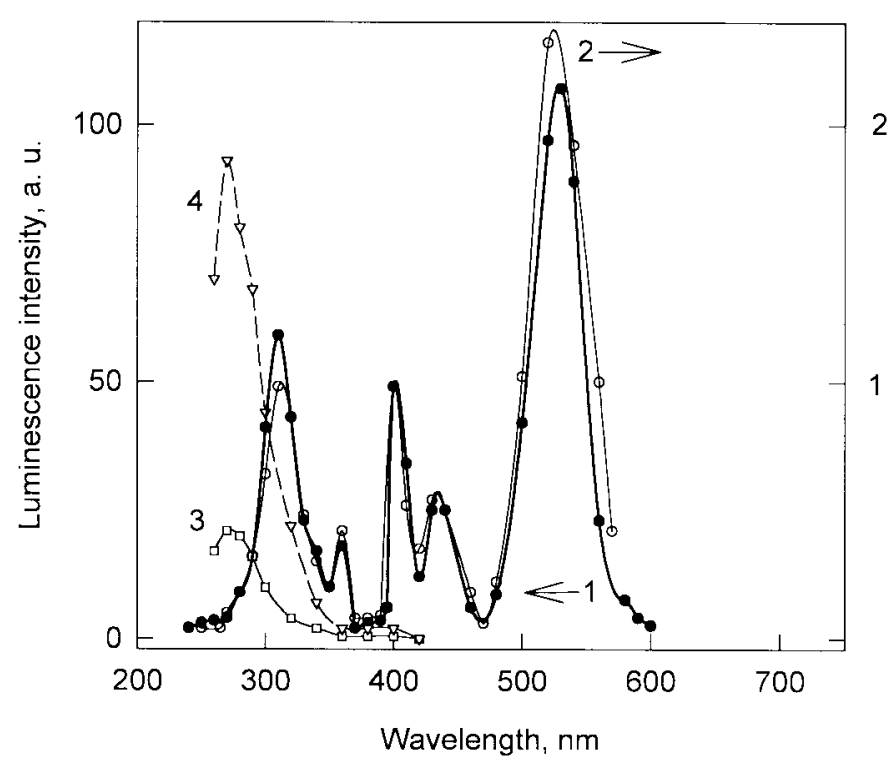

Fig. 2. OSA stimulation spectra of Iceland spar for two different delay times $\Delta t: 1$, integrated emission for a delay time of $1.5 \mathrm{~ms}$; 2, integrated emission for a delay time of $150 \mathrm{~ms}$; 3, blue emission (near $410 \mathrm{~nm}$ ) for a delay time of $1.5 \mathrm{~ms}$; 4, blue emission (near $410 \mathrm{~nm}$ ) for a delay time of $150 \mathrm{~ms}$. Note that different luminescence intensity scales are used for curves 1,3 , and 4 (on the left) and curve 2 (on the right). According to the data of Fig. 1, the red band of $\mathrm{Mn}^{2+}$ ion emission dominates in the integrated emission. 


\section{Calcite from dolomite deposits of Vasalemma and Saaremaa (Estonia)}

The shapes of OSA spectra of calcite from dolomites of Vasalemma (Fig. 3) and Saaremaa are very similar. They reflect luminescence of $\mathrm{Mn}^{2+}$ ions and the blue radiation separated by optical light filters, for a delay time of $50 \mathrm{~ms}$. These spectra differ from the corresponding spectra of Iceland spar only in more distinctive separation of short-wave $\mathrm{Mn}^{2+}$ bands. They do not depend on the radiation dose or optical bleaching. Complicated phenomena in the process of optical bleaching were also observed.

\section{Mollusc shells}

As natural carbonates may be very old, the accumulated radiation energy might have approached the saturation level. We measured the OSL spectra of recent and old mollusc shells. The spectra differ in details among shells of the same origin and for outer and inner parts of unprepared specimens (Fig. 4). There are, however, some common trends:

1. the emission and excitation characteristic of $\mathrm{Mn}^{2+}$ ions were not observed in any sample;

2. the luminescence intensity of the OSA spectra near the $400 \mathrm{~nm}$ wavelength of the integrated emission (without optical light filters) is noticeably higher than that of the blue emission (Fig. 5);

3. the shape of OSA spectra of mollusc shells resembles the shape of calcite spectra obtained with a blue optical light filter (see Figs. 3 and 5).

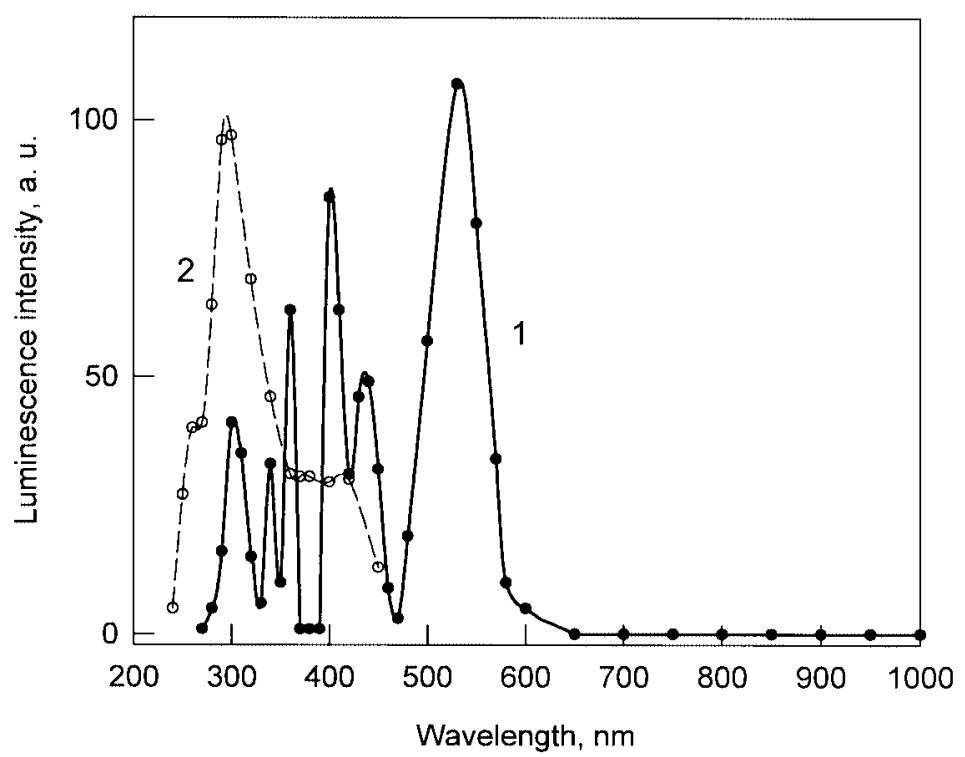

Fig. 3. OSA stimulation spectra for two different emission bands of calcite from dolomite deposits (Vasalemma, Estonia): 1, integrated emission for a delay time of $50 \mathrm{~ms} ; 2$, blue emission (near $410 \mathrm{~nm}$ ) for a delay time of $50 \mathrm{~ms}$. Similarly to Iceland spar the integrated emission is in essence the $\mathrm{Mn}^{2+}$ ion emission. 


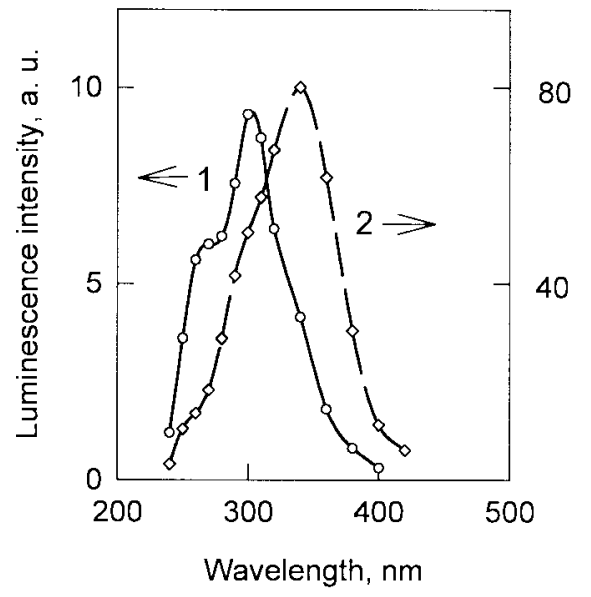

Fig. 4. OSA stimulation spectra of ancient mollusc shells from Suurupi, shore of the Gulf of Finland, Estonia. Blue emission (near $410 \mathrm{~nm}$, optical light filters CC-8 and C3C-22): 1, before heating; 2, after heating up to $500^{\circ} \mathrm{C}$. Delay time $50 \mathrm{~ms}$.

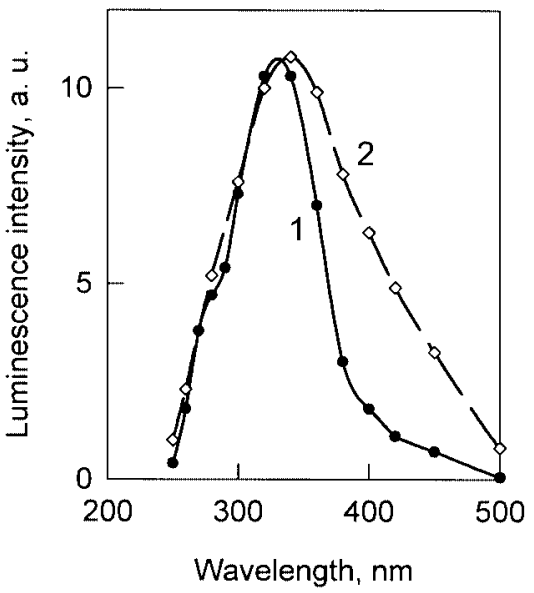

Fig. 5. OSA stimulation spectra of recently formed mollusc shells (Lithuanian seashore): 1, delay time $50 \mathrm{~ms}$, blue emission (near $410 \mathrm{~nm}$, optical light filters CC-8 and $\mathrm{C} 3 \mathrm{C}-22)$ at room temperature; 2 , integrated emission at room temperature for a delay time of $50 \mathrm{~ms}$. In the OSA spectra of mollusc shells no traces of the spectrum shape characteristic of $\mathrm{Mn}^{2+}$ ions can be observed even in integrated emission.

There is no correlation between the age of mollusc shells and the OSA signal intensity. However, the OSA signal intensity of shells from Lithuania is 15 times higher than that of shells from Suurupi. The OSA signal intensity did not decrease by heating, but the shape of the spectra changed slightly and the integrated luminescence intensity increased.

Very complicated phenomena occur in the process of optical bleaching. Intense radiation treatment of mollusc shells ( $300 \mathrm{~W} \mathrm{Hg-lamp} \mathrm{for} 20 \mathrm{~min}$ ) decreased the OSA signal at the $290 \mathrm{~nm}$ wavelength by 5.5 times. After storage in absolute darkness for five days the signal intensity regained up to $70 \%$ of its initial value. A following heating restored the initial signal intensity in full or even over $100 \%$ (Fig. 6). Additional X-radiation did decrease rather than increase the OSA signal intensity. After optical bleaching the X-raying did not restore the initial OSA signal intensity. 


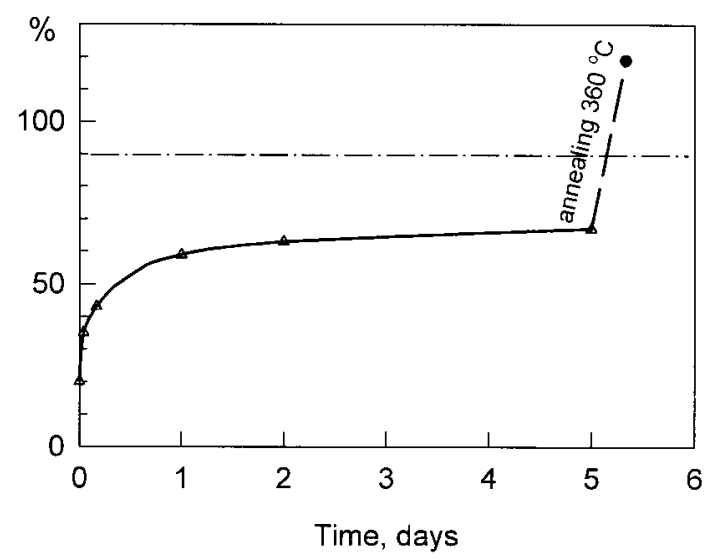

Fig. 6. Time dependence of the OSA signal intensity (stimulating light pulses $\lambda=290 \mathrm{~nm}$ ) after the sample from Suurupi was $20 \mathrm{~min}$ radiated with a $300 \mathrm{~W}$ Hg-lamp. The $100 \%$ level denotes the signal intensity before exposure. The last point on the graph represents the signal intensity after the dark pause of five days at room temperature and the following heating of the sample up to $360^{\circ} \mathrm{C}$.

\section{DISCUSSION}

From the above experiments we can conclude that it is extremely difficult to establish the existence of dose-sensitive stimulation bands in manganesecontaining calcites. Our conclusions, however, contradict the results of Okura et al. (1999). Obviously, there is a principal difficulty in the measurement of OSL signals in a spectral region at wavelengths shorter than emission spectra by using the spectral separation method. As a rule, the fluorescence excitation bands of the corresponding luminescence centres are situated in this spectral region. Thus, any OSL (OSA) signal related to traps is at its best a small difference of two signals of high magnitude (the fluorescence with the OSL signal minus the fluorescence of an unexcited specimen).

Even the OSA method cannot completely overcome this difficulty. Due to the long lifetime $\tau$ of the excited state of $\mathrm{Mn}^{2+}$ centres our apparatus could not distinguish the decay of intracentral luminescence from afterglow. The shape of the spectra closely resembled the $\mathrm{Mn}^{2+}$ excitation spectrum in calcites investigated by Marfunin (1979). Therefore, and as X-raying, as well as heating up to $360^{\circ} \mathrm{C}$ in $\mathrm{CO}_{2}$ atmosphere, changed the intensity of this signal by only $2-3 \%$, the observed OSA spectra of Iceland spar and calcites are in essence the excitation spectra of $\mathrm{Mn}^{2+}$ ions fluorescence. The decay time of other luminescence centres is noticeably shorter (about $0.02 \mu \mathrm{s}$; see Bahtin \& Gorobets 1992). Because of that no additional excitation bands of other centres were found although the OSA spectra were detected without any optical light filters. The red and infrared regions of the OSA spectra, where the Xe-lamp intensity is at its highest, did not contain any dose-sensitive signals. 
One of the possible solutions could be application of the emission of other luminescence centres with $\tau<10^{-2} \mathrm{~s}$. As these OSA signals are not dose-sensitive either, we believe that the OSA spectra of "blue" centres are actually the excitation spectra of primary phosphorescence of calcites. If this interpretation of experimental data describes the true situation, then the calcites must be sensitive to sunlight, which causes an additional population of traps.

The phenomena observed in the process of optical bleaching of short-wave bands of OSA spectra are easy to explain if we assume that only optical ionization of luminescence centres takes place, as is the case also with X-ray radiation. During the dark pause the initial (unionized) state of centres is restored. The following heating process speeds up this restoration as the electrons, trapped in deeper traps, are also effectively released. In all cases these stimulation bands are not related to any traps.

\section{CONCLUSIONS}

We did not find any dose-sensitive OSL signals that could be applied to dating. However, as TL experiments have shown that the corresponding deep traps must exist in calcites, it is very unlikely that the optical release of charge carriers from them is impossible. We suppose that the optical phenomena described in our paper conceal the process we have been searching for, so it is impossible to detect it by using our methods and X-ray radiation with the dose $D_{\mathrm{x}} \leq 300 \mathrm{~Gy}$. As dose-sensitive OSL is absent under standard measurement conditions, the carbonates investigated in this study differ from other natural (as well as man-made) materials, used as luminescence dosimeters (quartz, feldspars, also $\mathrm{CaF}_{2}-\mathrm{Mn}, \mathrm{Al}_{2} \mathrm{O}_{3}$, etc.). Quite probably the OSL and OSA signals, related to deep traps, can be detected if we introduce proper changes in the conditions of our experiments. First, the delay time used in OSA measurements should be increased about tenfold, so that the $\mathrm{Mn}^{2+}$ ion fluorescence could decay completely. The use of the apparatus with higher sensitivity would permit us to record the more slowly decaying secondary phosphorescence. To realize this programme, substantial changes in the experimental apparatus are required, but at present we have no right to state that it is impossible to perform the optical dating using natural carbonates. We firmly believe that the search for dose-sensitive OSL response in the natural carbonates should be continued.

\section{ACKNOWLEDGEMENT}

The present study was financed by the Estonian Science Foundation (grant No. 4049). 


\section{REFERENCES}

Aitken, M. J. 1998. An Introduction to Optical Dating. Oxford Univ. Pr.

Aitken, M. J. \& Bussel, G. D. 1982. Dating of fallen stalactites. PACT, 6, 550-554.

Bahtin, A. I. \& Gorobets, B. S. 1992. Optical Spectroscopy of Minerals and Ores. Kazan Univ. Pr. (in Russian).

Gallois, B., N'Guegen, B. H., Bechtel, F. \& Schvoerer, M. 1979. Datation par thermoluminescence de coraux fossiles des Caraibes; observation et interprétation de mécanismes inhabituels de TL. PACT, 3, 493-505.

Huntley, D. J., Gotfrey-Smith, D. I. \& Thewart, M. L. W. 1985. Optical dating of sediments. Nature, 313, 105-107.

Hütt, G., Jaek, I. \& Vasilchenko, V. 2001. Photoionization of radiation induced traps in quartz and alkali feldspars. Appl. Radiat. Isot., 54, 175-182.

Jaek, I., Hütt, G. \& Streltsov, A. 1999. Study of deep traps in alkali feldspars and quartz by the optically stimulated afterglow. Radiat. Protect. Dosim., 84, 467-470.

Lewis, D. R. 1968. Effect of grinding on TL of dolomite, calcite and halite. In TL of Geological Materials (MacDougal, D. J., ed.), pp. 125-132. Academic Pr.

Li Hu Hou. 1988. Properties of TL and ESR in deposited carbonates. Nucl. Tracks Radiat. Meas., 14, 259-265.

Marfunin, A. S. 1979. Spectroscopy, Luminescence and Radiation Centers in Minerals. Springer, Berlin.

Nambi, K. S. \& Mitra, S. 1978. Thermoluminescence investigations of natural calcite crystals of differing genesis. Thermochim. Acta, 40, 1095-1105.

Ninagawa, K., Adachi, K., Uchimura, N., Yamamoto, I., Wada, T., Yamashita, Y., Takashima, I., Sekimoto, K. \& Hasegawa, H. 1992. TL dating of calcite shells in the Pectinidae family. Quat. Sci. Rev., 11, 121-126.

Okura, C., Kaibara, Y., Yoshimura, S., Ninagawa, K., Nishido, H., Yamamoto, I., Yamashita, N., Kawana, T. \& Nakagawa, M. 1999. Optically stimulated luminescence of calcite and its application to dating. In Book of Abstracts LED'99, p. 13. Rome.

Roque, C., Guibert, P., Vartanian, E., Bechtel, F. \& Schvoerer, M. 2001. Thermoluminescence dating of calcite: study of heated limestone fragments from Upper Paleolithic layers at Combe Sauniere, Dordogne, France. Quat. Sci. Rev., 20, 935-938.

Turetken, N., Ozer, A. M., Kolat, A. \& Göksu, Y. 1979. TL and ESR studies of stalactites from a cave in the southern part of Turkey. PACT, 3, 266-280.

Wintle, A. G. 1975. Effects of sample preparation on the TL characteristics of calcite. Mod. Geol., 5, 165-167.

Wintle, A. G. 1978. A thermoluminescence dating study of some Quaternary calcite: potential and problems. Canadian J. Earth Sci., 15, 1977-1986.

\section{DOOSIST SÕLTUVA OPTILISELT STIMULEERITUD LUMINESTSENTSKOSTE OTSING LOODUSLIKES KARBONAATIDES}

Ivar JAEK, Galina HÜTT, Ilmar RAMMO ja Valeri VASSILTŠENKO

Selgitamaks elektron-paramagnetresonants- ja termoluminestsentspaleodosimeetritena kasutatavate erineva geneesiga karbonaatide (islandi pagu, kaltsiit, 
molluskite kojad) sobivust optiliselt stimuleeritud luminestsentsi abil dateerimiseks, mõõdeti nende järelhelenduse stimulatsiooni- või ergastusspektreid lainepikkuste vahemikus $250-1100 \mathrm{~nm}$. Islandi paos ja kaltsiidis on need spektrid integraalse kiirguse puhul interpreteeritud kui $\mathrm{Mn}^{2+}$-ioonide fluorestsentsi ergastusspektrid, molluskikodade ja kaltsiidi lühilaineliste ribade puhul aga primaarse fosforestsentsi ergastusspektritena. Ergastusribad viimastes on tundlikud optilise väljakiiritamise suhtes. Seoses nende ribade iseenesliku taastumisega pimepauside ajal on väljakiiritust interpreteeritud kui vastavate luminestsentsitsentrite optilise ionisatsiooni resultaati.

Stimulatsioonitsentrites ei leitud aga ribasid, mis oleksid seotud sügavate, termoluminestsentsi kaudu detekteeritavate haardetsentritega ja vastavalt sellele tundlikud röntgeniseerimise ja kuumutamise suhtes. Nimetatud tundlikkus on nende dateerimisel kasutatavuse põhitunnus. On analüüsitud sellise luminestseeruvate kristallide jaoks ebatavalise olukorra põhjusi ja võimalusi ületada karbonaatide optilist dateerimist takistavad raskused.

\title{
ПОИСК ЗАВИСЯЩЕГО ОТ ДОЗЫ ОПТИЧЕСКИ СТИМУЛИРОВАННОГО ЛЮМИНЕСЦЕНТНОГО ОТКЛИКА В ПРИРОДНЫХ КАРБОНАТАХ
}

\author{
Ивар ЯЭК, Галина ХЮТТ, Ильмар РАММО и Валерий ВАСИЛЬЧЕНКО
}

В целях выяснения применимости карбонатов различного генезиса (исландского шпата, кальцита, раковин моллюсков) в качестве палеодозиметров с оптической стимуляцией люминесценции были измерены их спектры стимуляции и возбуждения послесвечения в интервале длин волн 250-1100 нм. Используя при регистрации этих спектров интегральную эмиссию разных типов кальцита и исландского шпата, они интерпретируются как спектры возбуждения флуоресценции ионов $\mathrm{Mn}^{2+}$, для коротковолновых полос излучения раковин и кальцита - как спектры возбуждения первичной фосфоресценции. В последнем случае полосы возбуждения чувствительны к оптическому высвечиванию, однако в связи с самопроизвольным восстановлением этих полос во время темновых пауз высвечиваемость интерпретирована как результат оптической ионизации соответствующих центров люминесценции.

Однако в спектрах стимуляции не найдены полосы, которые были бы связаны с глубокими уровнями захвата, успешно детектируемые по термолюминесценции, и которые в согласии с этим были бы чувствительны к рентгенизации и прогреву. Проанализированы причины такой необычной для люминесцирующих кристаллов ситуации. 